\title{
Kinetic of Azo Dyes Decolourization by Enterobacteriaceae Species in the Intact Cell Assay System
}

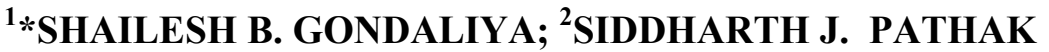

\author{
${ }^{*}$ M.B.S. Institute of Biochemistry, Saurashtra University, Rajkot, GUJARAT, India.-36005 \\ ${ }^{2}$ Department of Biosciences, Saurashtra University, Rajkot, India.
}

\begin{abstract}
The method "Intact cell assay" was adopted to assess the influencing factors on the process of decolourization ability of the enterobacteriaceaea specie isolates under predisposed environment. Taken into account several ingredient are added individually as well in combinations in the assay reaction. Values of dye decolourized in $\mu \mathrm{g}$ $\mathrm{ml}^{-1}$ with Multi vitanmins solution (MVS) with glucose 42.53; MVS 36.00; Riboflavin (RF) 39.00; Yeast extract 36.00 and B- complex 23.00 from the initial dye of $46.00 \mu \mathrm{g} \mathrm{ml}^{-1}$ were observed, where as glucose, Ascorbic acid, Cysteine, Cetyl-trimethyl-ammonium bromide (CTAB), Sodium molybdate, Biotin, $\mathrm{KNO}_{3}, \mathrm{NaNO}_{2}$, folic acid and 1-amino-2naphtho-4-sulfonic acid (ANSA) does not shows influence on to the process, but, some of them showed inhibitory effect toward the decolourization. It was observed that the riboflavin addition at $19.95 \mathrm{n} \mathrm{moles} \mathrm{ml}^{-1}$ in the reaction mixture, rate of decolourization was suddenly change from $0.019 \Delta \mathrm{A} /$ minutes to $0.20 \Delta \mathrm{A} /$ minutes, which is extremely high by 10 fold fast and subsequently remains faster i.e $0.2 \Delta \mathrm{A} /$ minutes without further additional $\mathrm{RF}$ in the same assay mixture. Rate of decolourization with different concentrations of riboflavin i.e. $13.0 \mathrm{n} \mathrm{moles} \mathrm{ml}^{-1}$ to $59.9 \mathrm{n} \mathrm{moles} \mathrm{ml}^{-1}$ showed second order kinetic. This indicates that the minimum amount of RF is essential to trigger the process of decolourization by the intact cells under the assay condition. While five different azo dyes were subjected, showed diverse behavior on to the rate of decolourization. Results of entire study incite on role of riboflavin could to a certain extent act as a redox mediator in the reaction(s) process and electron mediator between intracellular pool to the dye available at periplasmic redox sink@JASEM
\end{abstract}

In recent years a large number of microorganisms have been isolated which are able to degrade compound which previously was considered to be non degradable. In nature there is a significant resource of biological agents, which can be nourished to be exploited and employed for biotechnological applications. Most microbial activities that can serve the basis of bioremediation do not function optimally under the process conditions. It is thus become necessary to isolate potent microbes and study their environmental requirements for their best expression and performance for degradation/ decolourization in the nature. Studies and explanation view of decolourization to degradation and ultimate mineralization varied due to diversity in the both. As allude in literatures, azo dye decolourization is a reductive process in which azo $-\mathrm{N}=\mathrm{N}$ - bond (s) is converted to $-\mathrm{HN}-\mathrm{NH}-$ or 2 molecules of $\mathrm{NH}_{2}$ by the reductive enzymes present in specified bacterial strains. The products generated in process are two aromatic amines that do not absorb light in the visible spectrum and therefore azo dye reduction represents a decolourization process (Tan 2001) Several studies have published on the anaerobic decolourization of azo dyes by using intestinal anaerobic bacteria that subsequently found to be decolorized with various other anaerobic cultures (Walker and Ryan 1970, Allan and Raxon 1974, Chung et al. 1978, Brown and Laboureur 1983, Chung et al 1992, Carliell et al. 1994, Donlon et al. 1997, Razo-Flores et al. 1997, Beydilli et al. 1998). On the other hand azo dye reduction is a ubiquitous capacity of many microbes under anaerobic condition (Walker et al 1970, Rafii and Carliell et al. 1995, Donlon et al. 1997, Razo, Flores et al. 1997). An aerobic azo dye bioremediation also possible only by the bacterial consortium, but time required in days for decolorized $90 \%$ out of $50 \mu \mathrm{g} / \mathrm{ml}$ concentration (Senan et al 2004), which not feasible at field level due to high volume of the effluent, Further in biodecolourization with anaerobic bacteria, according to Gingell and Walker (1971) and Haug et al. (1992) required electrons for the reductive cleavage of azo dyes which may derive from co-substrates. Nigam et al. (1996a) also reported the similar results thus Azo dye reduction by the microbes requires co-substrate as a source of electron equivalent. Various records on the types of co-substrates used to suit as electron donors were, glucose (Carliell et al. 1995), Nigam et al. (1996a), hydrolyzed starch (Willetts et al. 2000), topioca (Chinwekitvanich et al. 2000), yeast extract (Nigam et al. 1996a), a mixture of acetate, butyrate, propionate (Donlon et al. 1997, Van Der Zee et al. 2000) and the azo dye reduction product like 5aminosalicylic acid as well (Razo-Flores et al. 1997) are recorded. Anaerobic decolourization of azo dyes by bacteria, the reduction equivalents generated by the oxidation of auxiliary substrates, i.e. organic carbon complexes act as electron donor through $\mathrm{NAD}(\mathrm{P})^{+}$reduce the azo bond via primarily assuming electron carriers (coenzymes) flavins nucleotides (FMN, FAD) or riboflavin as cofactors (Roxon et. al. 1967; Zimmermann et al. 1982, Rafii et at 1990, Chung and Stevens 1993). So incite that 
reactions may be multi steps and complex to fulfill intracellular donor to xenobiotics (dyes) in the system

The study of enzymes and enzyme-catalyzed reactions has contributed greatly to our understanding of microbial metabolism (Philips, 1999). It is always not possible to measure physiological or biochemical processes of bacteria by working with enzymatic reactions individually and to obtain molecular mechanisms. Philips (1999) again discusses the use of native intact cells to overcome the assays of individual enzymes due to the inability to make substances available to the enzyme in known and nonmilitant conditions. Several workers have recognized that causative agent(s) ought to be studied and also it is important, the native intact cell studies provide the confirmation of the existence of the causative agent(s) and also considerable mechanistic detail. This is also called in vivo method of quantitatively measurement of the process, which is not impossible, in vitro but necessitates expensive and cumbersome techniques. In this study decolourization rate was measured in different assay conditions created in the reaction mixture in vivo intact cell assay system to evaluate influencing parameter, subjective remarks that overall phenomenon are may operated by the reducing equivalents electron pool generated intracellular from anaerobic metabolism, then which are transfer from source to the azo dyes to reduce azo bonds via enzymatic system may at periplasmic place of the organism. Present study incite influences of supplementary substance and role of riboflavin on the kinetic of decolourization for establish a mechanism of the process for applications elaboration

\section{MATERIALS AND METHODS}

Dyes and chemicals: Four commercially available dyes, Reactive Magenta HB (C.I name Reactive Violate 13), Reactive Red PBX, Remazol Magenta HB, Sunzol Violet 5R were obtained from Saraf Chemical Ahemadabad, India and one laboratory dye Biebrich Scarlet was from BD chemical UK were selected for the studies purpose. stock solution of each dyes were prepared by dissolving $2.0 \mathrm{~g}$ of each dye in $100 \mathrm{ml}$ distilled water $\left(20 \mathrm{mg} \mathrm{ml}^{-1}\right)$, sterilized by autoclaving at $110^{\circ} \mathrm{c}$ for 30 minutes. Detailed structure of Reactive Violate 13 is Fig-A as a model structure available. All other chemical used are standard analytical grade produced from E Merck, BDH, S. D. fine chemical and Spectrochem, India

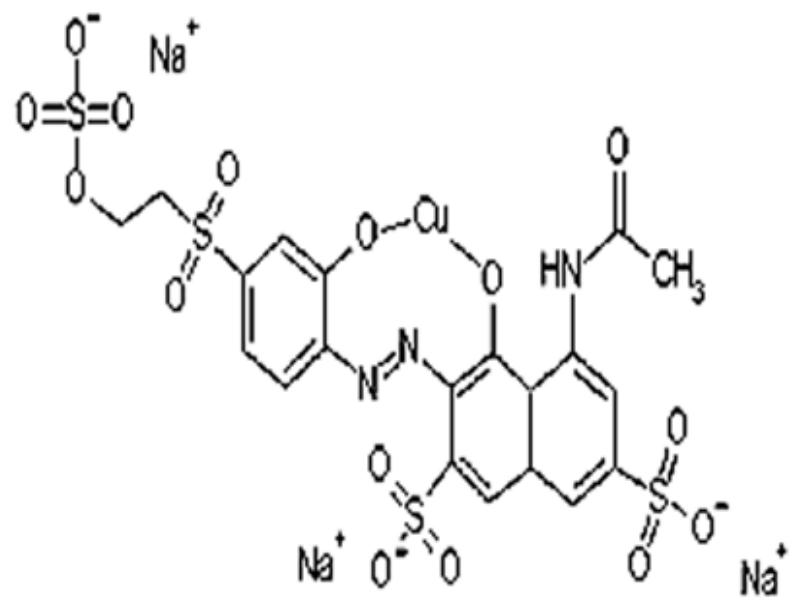

Fig 1. Ractive Violate 13; 5-acetamido-4-cupro-oxy-3-((4-((sulfooxy)ethyl) sulfophenyl (3-oxy(4-))azo)2,7-naphthalenedisulfonic acid trisodium salt

Organism: Enterobacteriaceae sp. was isolated from the activated sludge of comment effluent treatment plant of textile industrial waste. Isolation of microbial populations was carried out with direct enrichment and isolation techniques from the activated sludge in medium, selected most potent species were identified based in biochemical test with reference to Burgey"s Manual, selected strain Bio -3 belong to enterobacteriaceae species were conform.( Gondaliya and Pathak 2005) 
Medium: $\quad$ MM4 medium was used containing salts $\left(\mathrm{gL}^{-1}\right) \quad \mathrm{Na}_{2} \mathrm{HPO}_{4} 2.0, \mathrm{KH}_{2} \mathrm{PO}_{4} 2.0, \quad\left(\mathrm{NH}_{4}\right)_{2}$ $\mathrm{HPO}_{4} 4.0, \mathrm{NaCl} 2.0, \mathrm{Mg} \mathrm{SO} 47 \mathrm{H}_{2} \mathrm{O}$ 0.2, Sucrose 5.0, Yeast extract 1.0, and Trace elements solution $10 \mathrm{ml}$, to added per liter $\mathrm{pH} 7.0$ adjusted.

Preparation of intact cell broth for decolourization assays: After isolation and screening throughout procedure, most potent dye decolorizing microbial strain Enterobacteriaceae sp was maintained in agar slant. For preparation of intact cell broth, Enterobacteriaceae sp cultured in the $250 \mathrm{ml}$ conical flasks with medium MM4 containing dye (Remazol Magenta $\mathrm{HB}, 20 \mathrm{mg} \mathrm{L}^{-1}$ ) was inoculated with microbes from the preserved slant and incubated at $30 \pm 5^{0} \mathrm{c}$ temperature for 8 to 10 hours under static condition to get sufficient active biomass having 1.0 to 1.2 optical density. at $660 \mathrm{~nm}$ (high density of the bacterial cells). These activated acidified culture broth was neutralized to $\mathrm{PH} 7.5$ with addition of Sodium bicarbonate powder. The neutralized broth was adjusted to 1.00 optical density $\left(10^{-7} \mathrm{CFUml}^{-1}\right)$ at $660 \mathrm{~nm}$ to set the fixed amount of biomass with 0.5 $\mathrm{M}$ bicarbonate buffer $\mathrm{pH}$ 7.5. The preparation was made in $100 \mathrm{ml}$ volumetric flask, kept in tightly closed condition to avoid oxygen penetration in the cells preparation and are used as required to assay, Native intact cells assay method was followed to overcome the assaying of individual enzymes responsible for the biodecolourization by the microbial cells due to inability to make substances available to the enzymes in known and nonmilitant condition(s). To perform the assay termination and continued assay were followed.

Influence of various auxiliary substances on dye decolourization in native intake cell assay: Various chemical ingredients are added individually as well in combinations such as, multivitamin solution (MVS); MVS+ glucose; MVS + Cetyl-trimethylammonium bromide (CTAB); riboflavin (RF); ascorbic acid; sodium molybdate; sodium nitrite; sodium nitrate; Yeast extract; B-complex (BC); folic acid, biotin, 1-amino-2-naphtho-4-sulfonic acid (ANSA); and cysteine, were added in the assay mixture (in vial with screw cap $\Upsilon$ irradiated) at concentrations as mention in the fugures-1. Reactions were initiated by addition of dye fro stock $20 \mathrm{mg} \mathrm{ml}^{-1}$ to the assay mixture. Immediately after 1.0-hour incubation, the vials were centrifuged at 12000 RPM for $10 \mathrm{~min}$. in bench centrifuge (REMIRC24), optical density of the supernatants was measured by spectroscopically with spectrophotometer (Systronic 116A) at $540 \mathrm{~nm} \quad(\lambda$ max of dye). Results in dye content $\mu \mathrm{g} \mathrm{ml}^{-1}$ were calculated from optical density decrease per unit time from standard curve of dyes. All the values of graph in figure are means of nine samples reading were mean out in the excel graphic in all the cases.

Intact cell assay for dye decolourization rate determination: In continued assay, above prepared active intact cells broth $3.9 \mathrm{ml}$ was transfer in the cuvette and adjusted the spectrophotometer at 540 $\mathrm{nm}$ wavelength ( $\lambda$ max of dye Remazol magenta HB), set the 0.0 optical density with intact cell broth as a blank, to obtain base line of spectra, Initiation of the reaction in the cuvette was made by addition of dye $\left(50 \mu\right.$ from the stock solution $\left.20 \mathrm{mg} \mathrm{ml}^{-1}\right)$ gently mixed well and initial rate of decolourization was measured by monitoring the change in optical density at interval of a minute at R.T. $\left(30^{\circ} \mathrm{C}\right)$ up to the optical density reached to 0.0 or nearer to stable, assay were perform in the cuvette itself for the determination of influencing parameters; Rate of decolourization was expressed as a change in absorbance (A) units at $\lambda$ max of dye under a given time (a minute) of reaction with in defined assay condition. Rate of dye Decolourization $=\Delta$ Absorbance at $\lambda_{\text {-max }}$ of dye / minute.

Influence of $R F$ stepwise addition on dye decolourization rate in the reaction mixture assay:

In first set of assay, reaction was initiated with addition of dye with riboflavin, repeated the process by addition of dye only without RF in same assay cuvette. In second set of assay, reaction was initiated with dye without RF, followed with monitor change in optical density at $540 \mathrm{~nm}$ and then in the same cuvette RF at $19.95 \mathrm{n}$ moles $\mathrm{ml}^{-1}$ in the reaction mixture was added at the $14^{\text {th }}$ minutes, continued monitoring of decolourization rate at R.T. $\left(30^{\circ} \mathrm{C}\right)$ up to the optical density reached 0.0 or nearer to stable, subsequent repeated twice a time to measure rate. The rate of dye decolourization with and without riboflavin in the reaction assay were calculated from linear section of initial velocity

Effect of riboflavin concentrations on decolourization rate in intact cell assay: To

perceive whether the concentrations of riboflavin is effecting or not?, on the rate of decolourization by the intact cells in the assay system. Assay was performed with addition of varying concentrations of

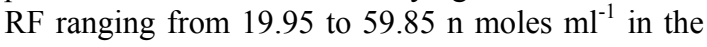
reaction mixture. Reaction was initiated with addition of dye solution and rate of decolourization was recorded against time on a minute scale interval up to stable absorbance.

Decolourization rate of different dyes in the intact cells assay: $\quad$ Five different dyes (Reactive Red PBX, Remazol Magenta HB, Reactive magenta HB, Sunzol Violet 5R and Biebrich Scarlet) were 
employed to determine the decolourization rate of the cells under given intact cell broth assay system. In the assay, reaction was initiated with addition of dye solution $\left(50 \mu \mathrm{l}\right.$ from the stock solution $20 \mathrm{mg} \mathrm{ml}^{-}$ ${ }^{1}$ ), gently mixed and the rate of decolourization ware measured by monitoring change in absorption at 540 $\mathrm{nm}$ at every minute interval up to the 0.0 absorbance at R.T. $\left(30^{\circ} \mathrm{C}\right)$. Results were directly as absorbance unit presented graphically, rate was expressed based on decrease in absorbance unit per a minute of time interval. In all the figures mean of nine samples reading were presented.

\section{RESULTS AND DISCUSSION}

It has been a major concern to remove color during the treatment processes of wastewater generating from dyestuff and textile industries. Generally, a customized process, which probably involves a combination of different methods, will be more applicable. Azo dyes decolourization was feasible only by first the reduction of dye under anaerobic that can be the initiate the further transformation process to ultimate degradation. Thus, to evaluate the factors that affecting on to the dye reduction kinetic under semi natural condition becomes an essential. Also decolourization has been consider as a specific task of microbes which were carried out under certain environmental condition created either themselves or to be provided to the culture broth in vitro or combination of both contributing to fulfill the process at optimally

As Philips (1999) discusses, assaying with intact cells is infrequently conducted for semi quantitative analysis and also he stated that the native intact cells assay would be better if the conditions where the investigators recognize those enzymes in which protein-protein or protein-membrane interactions are necessary or channeling the metabolic fluxes toward the particular function or if necessary energy flow to the enzyme form the cellular metabolisms, those normally found in the cells.

The study of enzymes and enzyme-catalyzed reactions has contributed greatly to our understanding of microbial metabolism (Phillips, 1999) It is always not possible to measure physiological or biochemical processes of bacteria by working with enzymatic reactions individually and to obtain molecular mechanisms. But, the use of native intact cells to overcome the assays of individual enzymes due to the inability to make substances available to the enzyme in known and nonmilitant conditions Also the exact keyed factor(s) may be known and not feasible to provide it in their physiologically required environment (i.e. as in vivo conditions). Therefore, assess of keyed factor(s) that affect on process of dye decolourization were undertaken with the bacterial cells. Organism was cultured in the defined cultural condition and then adjusted the biomass in suspension of intact cells with buffer of desire $\mathrm{pH}$ to maintain the semi natural environmental condition. In line of the experiments carried out, it was felt that to use whole cell assay to study the process of decolourization under varying assay conditions and to find out and understand the impacts of various parameters on dye decolourization.

Effect of various auxiliary substances on decolourization assay: Taken in to account several biochemical like, such as glucose, Yeast Extract, Ascorbic acid, Cysteine, MVS, CTAB, RF, Sodium molybdate, Biotin, $\mathrm{KNO}_{3}, \mathrm{NaNO}_{2}$, Bcomplex vitamin solution, folic acid and ANSA provided in the assay mixture and reactions were initiated by addition of dye (Remazol Magenta HB). Experiment values calculated as $\mu \mathrm{g} \mathrm{ml}{ }^{-1}$ dye decolourized were showed as MVS + glucose, (42.53 $\mathrm{g} \mathrm{ml}^{-1}$ ); MVS, (36.00); RF (39.00) and YE (36.00) from the initial value $46.0 \mu \mathrm{g} \mathrm{ml}^{-1}$ ), (Fig. 1) where as glucose, Ascorbic acid, Cysteine, CTAB, Sodium molybdate, Biotin, $\mathrm{KNO}_{3}, \mathrm{NaNO}_{2}$, , folic acid and ANSA does not effected to the process but some of them showed inhibitory effect toward the decolourization. However, from the results, it clearly shows that the intact cell assay required an essential auxiliary substance(s) that may present either in any components in MVS, YE, or might be only RF (riboflavin) that enhances the dye decolourization. The chemical reluctant, such as sodium molybdate, ascorbic acid, and ANSA, when added in the assay mixture to find out whether they could donate reducing power via the probable enzyme complex present on the cell surface to the dye, results showed that these reducing molecules did not play any role toward dye decolourization and but metabolically active cell and rich source of carbons in media has favor for the process showing evidence that the flow of reducing power must be originated intracellularly.

Addition of MVS with CTAB (CTAB acts as a nonionic detergent that disrupt the integrity of the cell membrane) in the assay mixture, further, provides a proof that even in combination of MVS the decolourization activity was lost. This could be explain, as the CTAB (0.05 to $0.1 \mathrm{mg} / \mathrm{ml})$ increases the permeability of the cell membrane (Phillips, 1999). But, in the assay mixture CTAB concentration was $1.0 \mathrm{mg} \mathrm{ml}^{-1}$, which was higher than the prescribed. Such a high concentration the integrity and functioning of the cells would be lost that consequently loosing supply of reducing equivalents to and from the membrane to the acceptor. It is clear evidence confirming that the 


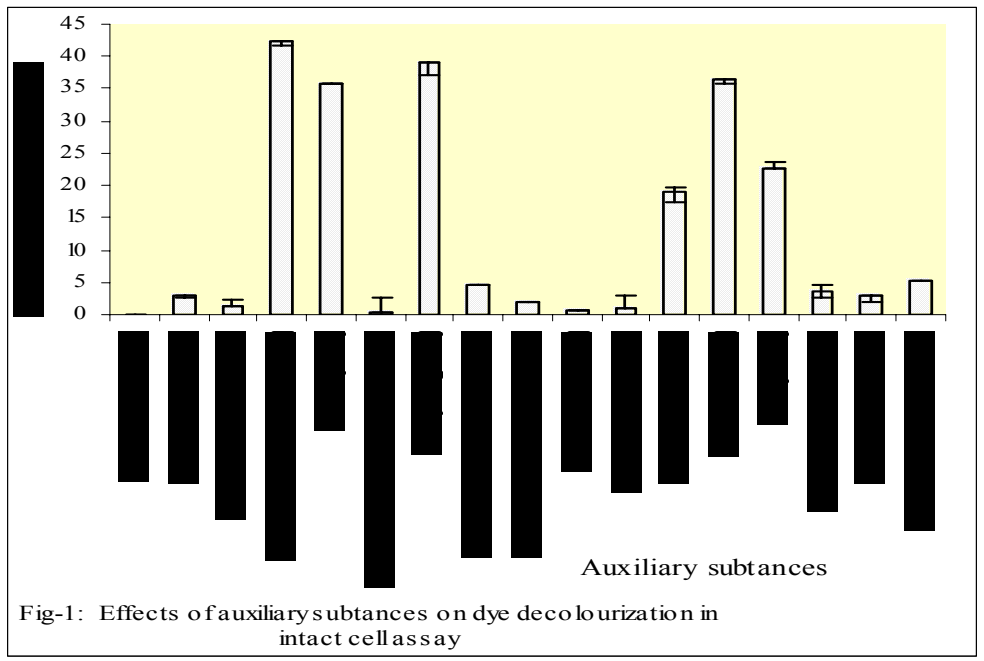

While in the continued assay system, following the conclusions has been drawn in under different assay conditions are as following:

Influence of $R F$ stepwise addition on dye decolourization rate in the reaction mixture assay:

During the time course of monitoring the change in optical density as decolourization in the two assays system as shows in Fig. 2 A \& B. Results in case of condition (i) decolourization process began immediately and ended at $7^{\text {th }} \mathrm{min}$. The same results were noted for the subsequent addition of dye to same reaction cuvette, i.e. every amendment showed dye decolourization within $7.0 \mathrm{~min}$. In the assay condition (ii), where reaction process initiated by adding dye (but without RF) showed very slow rate of decolourization i.e. 0.0199 A units/ minute and when RF was added at $14^{\text {th }}$ minute of on going reaction, showed rapidly 10 fold high change in rate of decolourization i.e. 0.200 A units/ minutes, with which reaction was completed within 7.0 to 8.0 minutes and also similarly in subsequent for every amendment. From kinetic data presented graphically for assay conditions (i) and (ii) clearly indicated with the addition of minimum amount of RF were significantly change in the rate of decolourization and also these is only once addition in low quantity are sufficient and necessary to get faster and efficient decolourization.

As observed in the figure 2.A.and 2.B.that without riboflavin in intact assay, rate determined was very slow which might be due to the indigenous availability of redox mediator or carrier to facilitate the processes of decolourization. In the reaction mixture by addition of RF in the continuous ongoing assay, rate significantly increased that of 10 fold that indicative that the RF playing a very important role in the process, it may be mediator as suggested by Field 2003. From the figure 2 B it also understand that once a addition of $\mathrm{RF}$ was sufficient and maintains high decolourization rate subsequently, so it was suggestive that RF would be non consumable entities in the reaction but simply playing as a carrier or as a cofactor in the reaction.

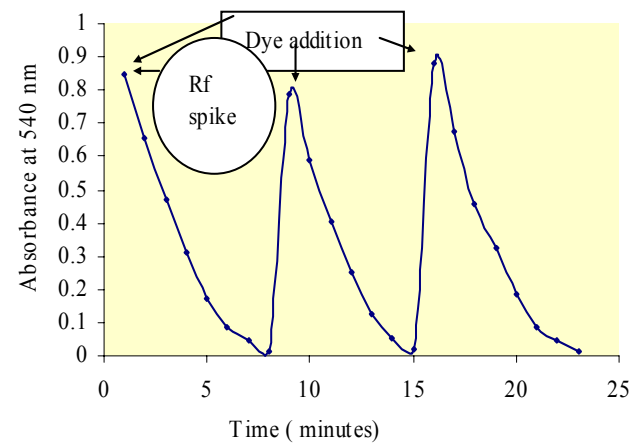

Fig-2A : Influence of Rf on the dye decolourization rate at initiation of reaction in intact cell assay 


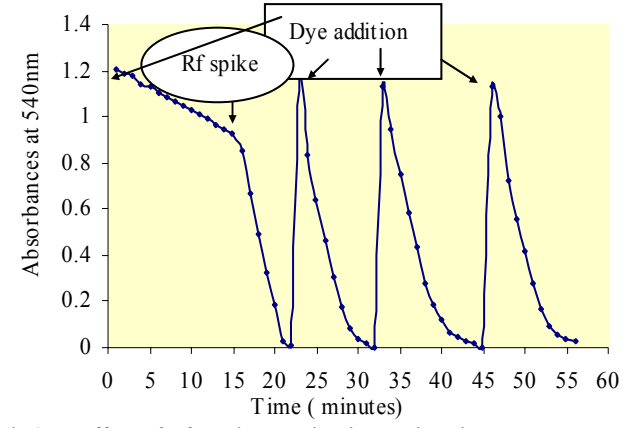

Fig 2B : Effect of $\mathrm{Rf}$ on the reaction in continued at

14 th minutes in continued in intact cell assay

Effect of $R F$ concentrations on decolourization rate in cell broth assay: Results were present graphically in Fig.3 showing the decolourization rates at the different concentrations of RF from 19.95 to $59,85 \mathrm{nM}$, rate of decolourization were increased from 0.126 to $0.154 \mathrm{~A}$ units which indicate that there are not significant change on rate of decolourization with varied concentrations, thus again indicates that minimum amount of RF required is sufficient and necessary for the efficient process of decolourization.

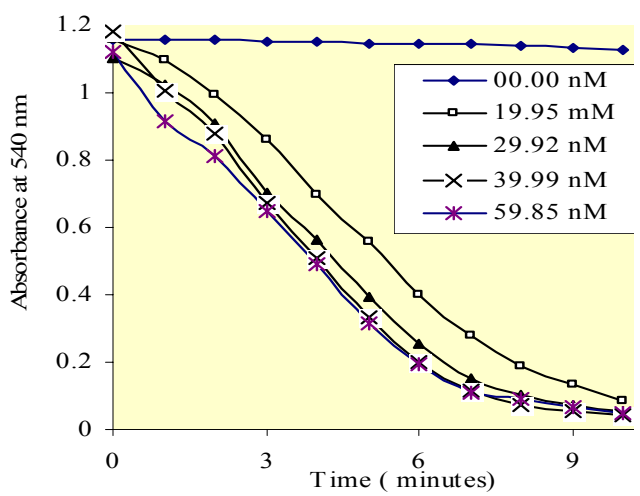

Fig- 3 Effect of Rf Concentrations on the dye decolourization in intact cell assay

Decolourization rate of different dyes in the intact cells assay: $\quad$ Five different dyes Reactive Red PBX (\# 23), Remazol Magenta HB (\# 26), Reactive magenta HB (\#1), Sunzol Violet 5R(\#35) and Laboretory Azo dye Biebrich Scarlet( \# 41) employed to determine the ability of the cells under given conditions. Fig. 4 shows the first four dyes could completely decolourized within almost 15 minute while, the dye Biebrich scarlet showed only about $50 \%$ decolourization within 15 minutes.

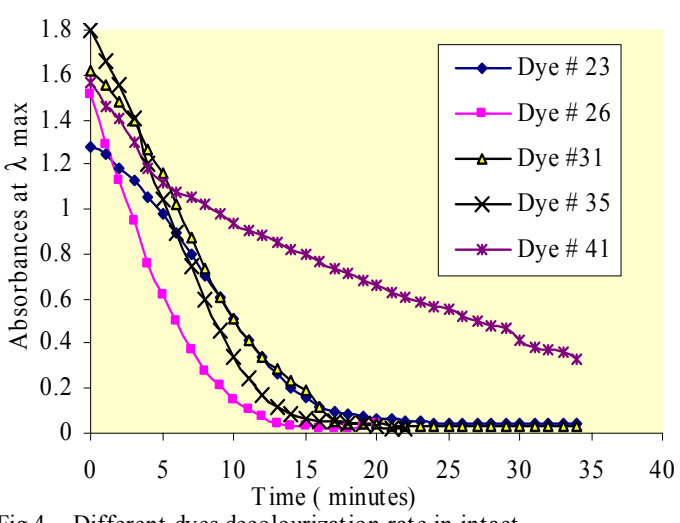

Fig 4 Different dyes decolourization rate in intact cell assay

Decolourization process are considered to be surface going on phenomenon, enzymatic as well as requires energy source in form of electrons as reducing equivalents for the azo bond reduction which generated from the co substrates (Nigam et al. (1996, Carliell et al. 1995, Willetts et al. 2000, Chinwekitvanich et al. 2000, Nigam et al. 1996a, Donlon et al. 1997, Van Der Zee et al. 2000. While during these studies, co substrata are not added extra in the preparation of cell broth due to indigenous components was sufficient for energy, otherwise it was necessary to be adding the co substrates for energy source (Gondaliya 2002). On one hand process is enzymatic, needs electrons as reducing equivalents to reduce the dye molecules, on second side, it occurs at the surface of the cell and requires co substrates for metabolic cellular energy to the microbes. Thus, there must be a some one as linker are needed to facilitate the process by the acting as carried between the cellular energy and periplasmic or outer surface where enzymes or proteins may lead to course of the decolourization.

Considering all the possibilities and physiological status of the cells at the time of decolourization as well as in anaerobic condition lead to electrons floods in the electron transport system of the membrane that make cell to force for respiration toward the sink of electrons (Taylor, 1999). The energy harvested by the cell during anaerobic respiration is then used to support other cellular processes that require energy consumption. Thus, many prokaryotes capable of performing anaerobic respiration (facultative / microaerophillic) can switch over to anaerobic respiration growth mode from aerobic. Many of these regulate their use of the alternative modes of energy generation in order to sustain growth and viability.

The difference in redox potentials between the acceptor (azo dye) and donor (the reductase - may 
be called azoreductase), transfer of reducing equivalents from the cofactor of the enzyme to the acceptor is highly favorable and the cells would continue to flood reducing equivalents to the azo dye in the external medium. Thus, to accomplish the process of transfer of reducing equivalents, the cells can explore the suitable (appropriate) and favorable acceptors occurring in their vicinity, that does not matter to them whether the acceptor(s) has any biological significance, since the goal of the cells is to become relieved from high reducing power to regenerate the oxidized state of cofactor (coenzyme) for their reuse. As we know riboflavin, FMN and FAD contain a cofactor riboflavin (vitamin) consisting of isoalloxazine ring that undergoes reversible reduction oxidation, accepting either one or two electrons in the form of hydrogen atoms from reduced substrates, usually the flavins are tightly bound to respective proteins. Quinone or ubiquinone , Menaquinone (found in prokaryotes) also known as coenzymes Q are a fat-soluble and plays role in carrying electrons in membrane-associated electron transfer chains. The $\mathrm{Q}$ is freely diffusible in the lipid bilayer of the membrane and acts as a shuttle (Lehninger et al. 1993) within membrane components. The coenzyme Q (or any other forms in bacteria) is unable to diffuse in the periplasmic space of the bacterial cells, where the enzymes may be reductases occurs. Thus, creating an imbalance (in terms of equilibrium) in the flux of reducing equivalents from the complex I or complex II Consequently, to sustain the flood of electrons from the complexes via coenzyme $\mathrm{Q}$, to translocation in the periplasmic space and attaining equilibrium toward the end-terminal acceptor(s), the cells may use any available carrier / mediator which are water soluble and act as shuttle between fixed donor to mobile acceptors (Azo Dyes) this type of propertied fulfill by the RF. Thus the study incite on role of riboflavin could to a certain extent act as a redox mediator in the reaction(s) process as suggested by the. Field 2003

Results of experiment were clearly established that auxiliary substances diversely influences the process depend on redox properties of it self and among all, the presence of riboflavin in the medium (as individual or in combined with other either in vivo or in vitro assay conditions), enhanced the kinetics of decolourization by acting as mediator between membrane component to extra cellular outer coat of organisms for reductive decolourization. However, this is the first report to my knowledge, expressing high degree of decolourization rate $\mathrm{i}$.e within 30 $\mathrm{min}$. to $60 \mathrm{~min}$. Currently we are continuing for the our study for establish a mechanism for the Azo dyes decolourization

\section{REFERENCES}

Allan R. and Roxon J. J. (1974). Metabolism by intestinal bacteria: the effect of bile salts on tartazine azo reduction. Xenobiotica. 4 (10): 637 $-643$

Beydilli, M. I., Pavlostathis, S. G. and Tincher, W. C. (1998). Decolourization and toxicity screening of selected reactive azo dyes under methanogenic conditions. Water Sci and Tech. 38 (4-5): $225-232$.

Brown D. and Laboureur P. (1983). The degradation of dyestuffs. Part-I: Primary biodegradation under anaerobic conditions. Chemosphere. 12 : $397-404$

Carliell C. M., Barklay S. J., Buckley C. A., Mulholland D. A. and Senior E. (1995). Microbial decolorization of a reactive azo dye under anaerobic conditions. Water SA. 21(1) : : $61-69$.

Chinwekitvanich S., Tuntoolvest M. and Panswad T. (2000). Anaerobic decolorization of reactive dyebath effluents by a two-stage UASB system with tapioca as a co-substrate. Water Research. $34(8): 2223-2232$.

Chung K. T. and Stevens S. E. Jr. (1993). Degradation of azodyes by environmental microorganisms and helminth. Environ. Toxicol. Chem. 12(11) : $2121-2132$.

Donlon B. A., Razo-Flores, E., Luijten M., Swarts H., Lettinga G. and Field J. A. (1997). Detoxification and partial mineralization of the azo mordant orange 1 in a continuous up flow anaerobic sludge-blanket reactor. A:lied Microbiology and Biotechnology. 47(1): 83-90.

Field J. A and J Brady (2003) Water Science and Technology. IWA Publishing, 48, (6) : 187- 103.

Gingell R. and Walker R. (1971). Mechanisms of azo reduction by streptococcus faecalis II. The role of soluble flavins. Xenobiotica. 1(3) : $231-$ 239.

Gondaliya S. B. and S. J. Pathak ( 2005) Isolation of textile dyes decolorizing microbes and their optimization of culture conditions. Asian Jr. of Microbiol. Biotech. Env. Sc. 7 ( 3) : 545-553

Gondaliya S. B. (2002) "Biodegradation of anthropogenic compounds by microbes" Ph. D. Thesis: ch 
Haug. W., Schmidt A., Normann B., Hempel D.C., Stolr A., Knackmas H. J. (1992). Mineralization of the sulfonated azo dye mordant yellow and by a 6-aminoaphthalene and sulfonate degrading bacterial consortium. A:1. Environ Microbiol. 57: $3144-3149$.

Lehninger (1993). Textbook of Biochemistry. $3^{\text {rd }}$ edition, Published by CBS.

Nigam P., Banat I. M., Singh D. and Marchant R. (1996a). Microbial process for the decolorization of textile effluent containing azo, diazo and reactive dyes.Process Biochemistry. $31(5): 435-442$.

Phillips A. T. (1999). "Enzymatic activity" in Methods for general and molecular bacteriology. (Ed. Philip Gerhardt) Ch. $23: 555-585$

Rafii F., Franklin W. and Cerniglia C. E. (1990). Azo reductase activity of anaerobic bacteria isolated from human intestinal microflora. Applied and Environmental Microbiology. 56(7) : 2146-2151.

Rafii F. and Cerniglia CE (1995). Reduction of azo dyes and Nitroaromatic compounds by bacterial enzymes from the human intestinal tract. Envion Health Perspect 103 (Su:1 5) : $17-19$.

Razo-Flores E., Luiten M., Donlon B. A., Lettinga G. and Field J. A. (1997). Complete biodegradation of the azo dye azodisalicylate under anaerobic conditions. Environmental Science and Technology. 31(7) : 2089-2103.

Roxon, J. J., A. J. Ryan, and S. E. Wright. (1967). Enzymatic reduction of tartrazine by Proteus vulgaris from rats. Fooptical densityCosmet. Toxicol. 5 : 645-656.
Senan R.C. and T.E Abraham (2004) Bioremediation of textile azo dyes by aerobic bacterial consortium Biodegradation. 15: 275280

Tan, N. C. G. and Field J. A. (2000). Biodegradation of sulphonated aromatic compounds. In: Environmental technologies to treat sulfur pollution. Principles and engineering, Lens P. and Hulshoff pol. L. IWA publishing, London.: $377-392$.

Taylor B. L., Zhulin B. I. and Johnson M. S. (1999). Aerotaxis and other energy sensing behaviour in bacteria. Annual. Rev. Microbiol. 53 : $103-$ 128.

Van der Zee F. P., Bouwman R. H. M., Strik D. P. B. T. B., Lettinga G. and Field J. A. (2000a). Application of redox mediators to accelerate the transformation of reactive azo dyes in anaerobic bioreactors, Biotechnology and Bioengineering,

Walker R. (1970) The metabolism of azo compounds: a review of the literature. Fooptical densityand Cosmetic Toxicology. 8: 659-676.

Willetts J. R. M., Ashbolt N. J., Moosbrugger R. E. and Aslam M. R. (2000). The use of a thermophillic anaerobic system for pretreatment of textile dye wastewater. Water Science and Technology. 42 (5-6): 309-316.

Zimmermann T., Kulla H. and Leisinger T. (1982a). Properties of purified Orange II azo reductase, the enzyme initiating azo dye degradation by Pseudomonas KF46. European Journal of Biochemistry. 12: 197-203 